\title{
Occurrence of antibodies to Toxoplasma gondii in rheas (Rhea americana) and ostriches (Struthio camelus) from farms of different Brazilian regions
}

\author{
Ocorrência de anticorpos Toxoplasma gondii em emas (Rhea americana) e avestruzes \\ (Struthio camelus) de propriedades de diferentes regióes brasileiras \\ Amanda Brentano Almeida ${ }^{1}$; Michelle Mayara Krindges ${ }^{1}$; Luiz Daniel de Barros ${ }^{2}$; \\ João Luis Garcia²; Giovana Camillo ${ }^{3}$; Fernanda Silveira Flores Vogel'3; Denise Nunes Araujo'; \\ Lenita Moura Stefani ${ }^{1,4}$; Aleksandro Schafer da Silva ${ }^{1 *}$
}

\begin{abstract}
${ }^{1}$ Departamento de Zootecnia, Universidade do Estado de Santa Catarina - UDESC, Chapecó, SC, Brasil
${ }^{2}$ Departamento de Medicina Veterinária Preventiva, Universidade Estadual de Londrina - UEL, Londrina, PR, Brasil

${ }^{3}$ Departamento de Medicina Veterinária Preventiva, Universidade Federal de Santa Maria - UFSM, Santa Maria, RS, Brasil

${ }^{4}$ Programa de Pós-graduação em Ciência Animal, Universidade do Estado de Santa Catarina - UDESC, Lages, SC, Brasil
\end{abstract}

Received June 8, 2013

Accepted July 31, 2013

\begin{abstract}
This study aimed to verify the occurrence of antibodies against Toxoplasma gondii in rheas (Rhea americana) and ostriches (Struthio camelus) commercially breeding in Brazil. Blood samples from 20 rheas and 46 ostriches (young and adults) were serologically tested using a technique known as modified agglutination test (MAT) at an initial titration of 1:16 for ostriches and 1:25 for rheas. Antibodies against T. gondii were found in 50\% (10/20) of the rheas, with titers ranging from 1:25 to 1:6,400. The incidence of antibodies against $T$. gondii in ostriches was $17.4 \%(8 / 46)$ with titers ranging from 1:16 to 1:256. Birds showing titers higher than 1:200 for T. gondii were mainly the young ones. Therefore, rheas and ostriches may be parasitized by $T$. gondii, showing high levels of antibodies against this parasite.
\end{abstract}

Keywords: Toxoplasmosis, ratites, serology.

\section{Resumo}

Este estudo teve como objetivo verificar a presença de anticorpos contra o Toxoplasma gondii em emas (Rhea americana) e avestruzes (Struthio camelus) criados comercialmente no Brasil. Amostras de sangue de 20 emas e 46 avestruzes (jovens e adultos) foram testadas sorologicamente pela técnica conhecida como teste de aglutinaçáo modificada (MAT) em titulaçōes iniciais de 1:16 para avestruzes e 1:25 para emas. Anticorpos contra T. gondii foram encontrados em 50\% (10/20) das emas com títulos variando de 1:25 a 1:6.400. A incidência de anticorpos contra T. gondii em avestruzes foi de $17,4 \%(8 / 46)$ com os títulos oscilando entre 1:16 e 1:256. Aves jovens foram aquelas que apresentaram títulos superiores a 1:200 para T. gondii. Portanto, emas e avestruzes podem ser parasitados por T. gondii, apresentando elevados níveis de anticorpos contra o parasita.

Palavras-chave: Toxoplasmose, ratitas, sorologia.

Toxoplasma gondii causes a parasitic disease of worldwide occurrence that has been identified in different species and is of great important as a zoonosis (MONTEIRO, 2011). Toxoplasmosis is a disease that is usually considered to be asymptomatic, because the host immune defense is able to control the infection and prevent further pathogenic damage. However, depending on the immune status (situations of poor nutrition, stress and immunosuppressive

\footnotetext{
*Corresponding author: Aleksandro Schafer da Silva

Department of Animal Science, Universidade do Estado de Santa Catarina - UDESC,

CEP 89815-630, Chapecó, SC, Brazil

e-mail: aleksandro.silva@udesc.br
}

diseases, among others), a decline in the immunological defenses may occur and the individual might develop a clinical stage of the disease (FAGUNDES, 2009). It has been found that when humans and animals are infected by $T$. gondii, they may have fever, lymphadenopathy and anorexia (BOWMAN et al., 2010; MONTEIRO, 2011). Previous studies described occurrences of positive serology for $T$. gondii in ostriches and rheas (DUBEY et al., 2000; MAROBIN et al., 2004; CONTENTE et al., 2009; SOARES et al., 2010).

Rheas (Rhea americana) and ostriches (Struthio camelus) are ratites found in different countries, being rheas typically 
found in South America. Ostrich and rhea farming has become a growing business in Brazil, serving as an agricultural activity of national and international importance (FILHO; LUCIO, 2006). As this activity has grown, there has been a trend towards increasing health problems in these birds, as well as bird mortality and expenses with treatments (FILHO; LUCIO, 2006). These birds are believed to have a great importance in the $T$. gondii life cycle, since they might be consumed by predators such as felines (BOWMAN et al., 2010; MONTEIRO, 2011). Likewise, it is likely that ratites are involved in the epidemiology of $T$. gondii in large wild felines. Therefore, the aim of this study was to detect antibodies against $T$. gondii in $R$. americana and $S$. camelus from Brazilian commercial herds.

In this study were evaluated two rhea farms in the municipalities of Rio Rufino, state of Santa Catarina, and Santa Maria, state of Rio Grande do Sul, in southern Brazil, and three ostrich farms from the municipalities of São Paulo, state of São Paulo, São Miguel do Oeste, state of Mato Grosso and Santa Maria, state of Rio Grande do Sul. The first rhea farm had 40 birds: 21 adults aged from 3 to 7 years, and 19 rhea chicks from 4 to 6 months of age. Blood samples were collected from only 17 young and adult birds (Table 1). From the second farm, blood samples were collected from three young rheas aged one year. The ostrich blood samples were well distributed: from farm of the State University of São Paulo in the city of São Paulo, were collected from 17 adult ostriches out of a total population of 30 birds; from a commercial farm with over 5,000 birds in São Miguel do Oeste, 20 ostriches of 14 months of age; and from a farm that was just starting in the business in Santa Maria, nine samples were collected. In this farm, adult birds had been living on this farm for the last two years (aged between 3 and 5 years), and young birds that were ten months of age at the time of sampling had been acquired at the age of three months. On all farms (rhea and ostrich), all the birds were kept on natural pasture and their diet was supplemented with commercial feed.

Blood samples ( 3 to $5 \mathrm{~mL} /$ bird) were collected using a needle (22 gauge) by means of brachial vein puncture. The samples were stored in tubes without anticoagulant, refrigerated at $10{ }^{\circ} \mathrm{C}$, transported to the laboratory and centrifuged at 3,500 $\mathrm{g}$ for $10 \mathrm{~min}$. Serum samples were stored at $-20^{\circ} \mathrm{C}$ until serological analysis for T. gondii.

Rhea and ostrich serum samples were assessed for antibodies against $T$. gondii by means of the modified agglutination test (MAT), accordance the methodology described by Desmonts and Remington (1980). The initial dilutions for the serum samples were 1:16 for ostriches (SOARES et al., 2010) and 1:25 for rheas (CONTENTE et al., 2009), in buffered saline solution. Thus, titers $\geq 1: 16$ and $\geq 1: 25$ were considered positive for ostriches and rheas, respectively. Based on this information, positive samples were further diluted in order to identify the maximum antibody titration for each bird.

Out of the 20 rhea serum samples analyzed using MAT, ten were identified as positive for $T$. gondii (50\% seropositive) (Table 1). These results were higher than those found by other researchers. In a study on 74 rheas from commercial farms in the state of Rio Grande do Sul, Brazil, 8.1\% were found to be positive for $T$. gondii using the hemagglutination test (MAROBIN et al., 2004). In another study on 69 rheas, $4.3 \%$ were found to showed antibodies against $T$. gondii (SOARES et al., 2010). In the present study, we found high anti-T. gondii titers (1:200, 1:3,200 and

Table 1. Antibodies against Toxoplasma gondii in rheas and ostriches on farms located in the municipalities of Rio Rufino, state of Santa Catarina; São Miguel do Oeste, state of Mato Grosso; and Santa Maria, state of Rio Grande do Sul, Brazil, according modified agglutination test (MAT).

\begin{tabular}{|c|c|c|c|c|}
\hline Birds & Gender & Age & $\begin{array}{l}\text { Farm location } \\
\text { (city and state) }\end{array}$ & Result/Titer \\
\hline Rhea & Female & 7 years & $\mathrm{RF} / \mathrm{SC}$ & Positive $-1: 25$ \\
\hline Rhea & Female & 7 years & $\mathrm{RF} / \mathrm{SC}$ & Positive - 1:25 \\
\hline Rhea & Female & 5 years & $\mathrm{RF} / \mathrm{SC}$ & Positive - 1:100 \\
\hline Rhea & Female & 5 years & $\mathrm{RF} / \mathrm{SC}$ & Positive - 1:100 \\
\hline Rhea & Female & 5 years & $\mathrm{RF} / \mathrm{SC}$ & Positive - 1:100 \\
\hline Rhea & Male & 3 years & $\mathrm{RF} / \mathrm{SC}$ & Positive - 1:200 \\
\hline Rhea & Female & 6 months & $\mathrm{RF} / \mathrm{SC}$ & Positive - 1:200 \\
\hline Rhea & Male & 6 months & $\mathrm{RF} / \mathrm{SC}$ & Positive - 1:3,200 \\
\hline Rhea & Female & 6 months & $\mathrm{RF} / \mathrm{SC}$ & Positive - 1:6,400 \\
\hline Rhea & Male & 4 months & $\mathrm{RF} / \mathrm{SC}$ & Positive - 1:200 \\
\hline Ostrich & Male & 14 months & $\mathrm{SMO} / \mathrm{MT}$ & Positive - 1:16 \\
\hline Ostrich & Male & 5 years & SM/RS & Positive $-1: 16$ \\
\hline Ostrich & Female & 3 years & SM/RS & Positive - 1:16 \\
\hline Ostrich & Female & 3 years & SM/RS & Positive - 1:16 \\
\hline Ostrich & Female & 3 years & SM/RS & Positive - 1:16 \\
\hline Ostrich & Female & 3 years & SM/RS & Positive - 1:64 \\
\hline Ostrich & Female & 10 months & SM/RS & Positive - 1:256 \\
\hline Ostrich & Female & 10 months & SM/RS & Positive - 1:256 \\
\hline
\end{tabular}

Rio Rufino, Santa Catarina (RF/SC); São Miguel do Oeste, Mato Grosso (SMO/MT); and Santa Maria, Rio Grande do Sul (SM/RS). Ostriches state of Sao Paulo were negative for $T$. gondii. 
$1: 6,400)$, particularly in young rheas ( 4 to 6 months of age). This finding might be related to recent infection in young ratites, thus suggesting that there is a strong immune response against the parasite.

One of the first studies on T. gondii seroprevalence in which 973 ostriches were sampled, found that $2.9 \%$ were considered positive (DUBEY et al., 2000). In the current study, $17.4 \%$ of the serum samples from ostriches had differing levels of antibodies against T. gondii, ranging from 1:16 to 1:256. These results were similar to those reported by Contente et al. (2009) in São Paulo, Brazil, that demonstrated $14.36 \%$ of seropositive for $T$. gondii. Considering 17 samples collected in the farm of São Paulo seronegative for T. gondii in the current study, is demonstrated that that the prevalence may depend mainly on the epidemiological situation.

The positivity for T. gondii in ostriches and rheas can be linked to several factors. Among these, the most important is free access by felines to environments shared by ratites like those investigated in the current study. Felines may have eliminated oocysts (the infective form) in their feces (MONTEIRO, 2011). Rheas and ostriches, along with many others (insects, worms, and small rodents) serve as intermediate hosts of $T$. gondii (RUIZ; FRENKEL, 1980). Therefore, rheas and ostriches play an important role in the epidemiology of toxoplasmosis when these birds ingest intermediate hosts infected by parasite, since they can be latter consumed by wild felines, infecting this predator (DUBEY; BEATTIE, 1988; MONTEIRO, 2011).

As previously mentioned, ostriches and rheas apparently showed no clinical changes, although young birds showed higher levels of circulating antibodies. Similar to ratites, toxoplasmosis in the intermediate host of backyard chickens (Gallus gallus domesticus) is usually asymptomatic (GARCIA et al., 2000). However, clinical signs have been recorded in some birds, such that eye and brain injuries have been seen to affect turkeys and canaries (QUIST et al., 1995; WILLIAMS et al., 2001). It has been found that implementing good sanitary management for these birds is important in order to prevent infection and environmental contamination. Thus, feed and water that are free from $T$. gondii should be provided, so as to decrease the prevalence of birds infected by the parasite, consequently reducing the risk of infection among humans (CONTENTE et al., 2009).

Based on these results, we conclude that the occurrence of T. gondii infection in $R$. americana and $S$. camelus varied among the farms investigated in Brazil. This study suggests that the young birds tested probably had been affected by recent infection, given that they presented higher levels of antibodies against the parasite.

\section{Ethical approval}

The procedure used was approved by the Animal Welfare Committee of Universidade do Estado de Santa Catarina (UDESC), under number 1.50.12.

\section{References}

Bowman DD, Lynn RC, Eberhard ML, Alcaraz A. Parasitologia Veterinária de Georgis. Tradução da 9a edição de 2008. Elsevier; 2010.

Contente APA, Domingues PF, Silva RC. Prevalência de anticorpos antiToxoplasma gondii em avestruzes (Struthio camelus) de criatórios comerciais no estado de São Paulo. Braz J Vet Res Anim Sci 2009; 46(3): 175-180. PMid:26764.

Desmonts G, Remington JS. Direct agglutination test for diagnosis of Toxoplasma infection: method for increasing sensitivity and specificity. J Clin Microbiol 1980; 11(6): 562-568. PMid: 273461. http://dx.doi. org/0095-1 137/80/06-0562/07\$02.00/0

Dubey JP, Beattie CP. Toxoplasmosis of animals and man. Boca Raton: CRC Press; 1988.220 p.

Dubey JP, Scandrett WB, Kwok OCH, Gajadhar AA. Prevalence of antibodies to Toxoplasma gondii in ostriches (Struthio camelus). J Parasitol 2000; 86(3): 623-624. PMid:10864266. http://dx.doi. org/10.1645/0022-3395(2000)086[0623:POATTG]2.0.CO;2

Fagundes TF. Ocorrência e sazonalidade de parasitos gastrintestinais em avestruzes (Struthio Camelus) de três faixas etárias em uma criação no município de Areal-RJ [Dissertação]. Seropédica: Universidade Federal Rural do Rio de Janeiro; 2009.

Filho A, Lucio R. Saúde aviária e doenças. São Paulo: Roca; 2006. 61 p.

Garcia JL, Navarro IT, Ogawa L, Marana ERM. Soroprevalência do Toxoplasma gondii em galinhas (Gallus gallus domesticus) de criaçóes domésticas, oriundas de propriedades rurais do Norte do Paraná, Brasil. Cienc Rural 2000; 30(1): 123-127. PMid:33113557020. http://dx.doi. org/10.1590/S0103-84782000000100020

Marobin L, Flôres ML, Rizzatti BB, Segabinazi SD, Lagaggio VRA, Grigulo M, et al. Prevalência de anticorpos para Toxoplasma gondii em emas (Rhea americana) em diferentes criatórios do Estado do Rio Grande do Sul. Braz J Vet Res Anim Sci 2004; 41(1): 5-9. PMid:95962004. http:// dx.doi.org/10.1590/S1413-95962004000100001

Monteiro SG. Parasitologia na medicina veterinária. São Paulo: Roca, 2011. 306 p.

Quist CF, Dubey JP, Luttrell MP, Davidson WR. Toxoplasmosis in wild turkeys: a case report and serologic survey. $J$ Wildl Dis 1995; 31(2): 255-258. PMid:8583648.

Ruiz A, Frenkel JL. Intermediate and transport hosts of Toxoplasma gondii in Costa Rica. Am J Trop Med Hyg 1980; 29(6): 1161-1166. PMid:7446807.

Soares HS, Alves ND, Pereira RHMA, Matos SM, Pena HFJ, Gennari $\mathrm{SM}$, et al. Ocorrência de anticorpos anti-Toxoplasma gondii em emas (Rhea americana) do Centro de Multiplicação de Animais Silvestres de Mossoró, Rio Grande do Norte. Arq Bras Med Vet Zootec 2010; 62(2): 489-491. PMid:551851. http://dx.doi.org/10.1590/S0102-09352010000200033

Williams SM, Fulton RM, Render JA, Mansfield L, Bouldin M. Ocular and encephalic toxoplasmosis in canaries. Avian Dis 2001; 45(1): 262-267. PMid:11332494. 